Kohl: a Journal for Body and Gender Research

Vol. 5, No. 2 (Summer 2019)

\title{
The Blindness of Political Economy: How Austerity Affects Women
}

Viviane Akiki 
I completed my education at the media faculty of the Lebanese University, where I specialized in journalism. There, I failed to notice the depth of gendered disparities. The classrooms' benches were populated with female students; more often than not, they outnumbered other genders. And yet, most teachers were men. Back then, what I considered to be a detail did not strike me as weird or unordinary.

Like other women, I faced my share of discrimination, in various shapes and forms, due to my life circumstances and trajectory. Following my father's unemployment, my mother was forced to accept harrowing work conditions in order to be able to support the family. I myself started working at a very young age to alleviate her burden. But I considered education to be my "savior," and a university degree my platform for "individual salvation" under a system that feeds off of competitive economies.

I am not exactly sure how I bought into the narrative of individual talent, hard work, productivity, and luck - a narrative that seems to exist in a political vacuum, despite it being engrained in the very system that upholds it. After completing my specialization, I pursued a degree in politics science in parallel with my journalistic work. I was convinced I only had to gain additional skills in order to accumulate a capital of "luck." All I had to do, I thought, was to intensify my efforts and prove myself in order to increase my career opportunities. Yet, I still faced discrimination; in fact, and despite having worked as a journalist for years, I still do, to this day, perhaps even on a wider scale. At home, women are isolated and their free, unpaid labor is exploited. In the workplace, women earn less than men, and do not have the same access to opportunities. In this dual context, women have to juggle between care work and paid jobs, in addition to having to contend with multiple kinds of violence, harassment, and subjugation.

As the current editor of the supplement "Capital" - a weekly economic supplement to Al Akhbar newspaper, I was able to immerse myself in the "political economy" of the social system we operate under, and make sense of the discriminations that I kept facing over and over again. Patriarchy and capitalism are twins: gender- and class-based discrimination take roots in and complement each other; they employ the same mechanisms of oppression and division of labor under a capitalist system. My new work experience made me aware that the approach of journalism, media, reports, and specialized conferences to the "economy" treats women as non-existent, and does not concern itself with its political and institutional impact on them. It is an approach that is only interested in women as long as their contribution in the labor market increases economic growth and accumulates capital, and their surplus value can be extracted via a "reserve army of labor" and low wages.

Within this context, the austerity measures and cuts to the 2019 budget undertaken by the Lebanese government exemplify the "blindness" of mainstream economy. The absence of feminist approaches to economic structures implies a compartmentalized system that does not look at economies in their totality, including those of the family, emotional ties, care work, and gender roles. By reducing their fiscal deficit, the government is buying itself and the economic status quo time, at the expense of basic services, the infrastructure, and social protection. Via budget cuts, it reduced its investment in health, care, and educational organizations and programs, in addition to lowering the wages of public employees, retirement plans, and the number of annual leave days, among other cuts. It also imposed custom duties on imported goods and 
increased taxation on benefits, interests, and other fees, without mentioning the targeting of migrant workers who have to come up with exorbitant fees to cover for residency and work permits.

Framed as "necessary reforms" that would avoid waste and inefficiency, these measures will hit working classes the hardest, and by extension, families and households. These reforms would further strain their own budget and fall into a cycle of unsustainability, due to the state not fulfilling its fundamental job - that of providing general services and social protection. In the past decades, this job has been deferred to civil society and sectarian organizations, with the state allocating funding to these associations. But the proposed measures will ultimately heighten the pressure on women, forcing them to accept unfair and poor working conditions under austerity, in addition to having to make up for the lack of care and support, as well as close the gap of the rising of prices and living expenses.

According to the Central Administration of Statistics, women constitute $23 \%$ of the total labor force in Lebanon's formal economy. Of these, and although $56 \%$ of university graduates are women according to the National Council for Scientific Research, more than $30 \%$ are categorized as unskilled workers. These figures corroborate previous studies' findings: women, unlike men, leave the workforce because of two events in their life, namely marriage and childbirth. This is mainly due to the patriarchal system that relegates care, domestic, and family work to women, without providing them with sufficient public or cheap services, such as kindergartens and elderly care. If they choose to marry and start a family, women do not find the structural support they need to their empowerment and contribution to the formal workforce. One of the World Bank's latest Human Capital Index estimates the projected value of each child born today, according to his/her health and educational circumstances. What that means in our economic context is that "children currently born on Lebanon soil will only ever explore $54 \%$ of their productive potential; the lack of adequate education of healthcare will prevent them from channeling their full capacities into production, taking away $46 \%$ of total economic potential" (Zbeeb 2018). ${ }^{1}$ The origin of this waste of production can be traced back to the decline of the "welfare state" and the exclusion of women, educated or not, from economic activities and life.

A clear misogyny lays within austerity measures, as they increase women's marginalization and exploitation, as well as gendered inequality. The amount of compulsory and unpaid care work increases under the current social system and labor divisions within it, placing an additional burden on women to substitute the state's role and duties in providing education, medication, care services, and social security. Women spend thousands of hours of unpaid work in caring for children, elderly and sick people, as well as cooking and cleaning. In its recently published report "Care Work and Care Jobs for the Future of Decent Work - 2018," the International Labor Organization states that "for every 303 minute a women in Lebanon give to childcare on daily basis, men contribute with a 111 minute," which amounts to one third of women's contribution only. The practice increases existing gendered inequalities that are now visible across contexts, including developed countries, and takes away from the time available to women, preventing them from allocating time for education and political and economic participation.

1 https://bit.ly/31F9bec 
Social protection systems, public services, and sustainable infrastructure constituted the principal discussion topics of the United Nations' 63 ${ }^{\text {rd }}$ Commission on the Status of Women, held last March. Provision by governments was considered the main actor in establishing gender equality and women and girls' empowerment. Thus, the state is considered both responsible for the safety and decent living of its population, and able to enforce adequate policies that would improve society, empower women, and strengthen their role and participation within the economy. Inevitably, this role is linked to the public policies the government ratifies to achieve its goals. However, these policies cannot be drawn separately from the social system and its political economy, i.e., disjointedly from changing awareness, interests, structures, and institutions; thinking otherwise seems naïve, and significantly resembles the path of some liberal women's movements that look at women's causes from a rights-based approach alone.

In Lebanon and other states, the economic system has played a negative role towards women in the different stages of its establishment. Despite bettering their position in education and health indicators, women's presence remains marginalized, as they still constitute the largest percentage of poor and refugee populations, as well as war, economic crisis, and modern slavery victims in the fields of domestic, sex, and agricultural work. Therefore, changing the status of women and liberating their energies towards work, production, creation, knowledge, and science does not seem possible without changing the current system to an alternative based on equality.

Currently, all what is dubbed "women empowerment policies" revolves around the creation of incompetent ministries and the launch of literacy, sewing, and knitting programs for women. What is needed, however, is a change in public policies, not only to support marginalized populations, but also to eradicate structural inequalities that sustain injustice, especially that women are amongst the most vulnerable populations in the face of economic crisis and changes within the labor structure.

These alternative policies need to take root in the recognition of unpaid domestic work as work and its inclusion within local production to reflect women's actual contribution into the economy. They would also increase pay by taking into account the gendered value of work, improve work conditions by decreasing the number of weekly working hours, and promote the right to yearly holidays and extending maternity leaves. This is without mentioning the protection of women from violence and harassment, as well as putting an end to discrimination, especially in the workplace. Most importantly, the state should adopt a fairer taxation system, by taxing profit and income at higher rates for the financing of public services that benefit the society at large and women in particular. For instance, the creation of nurseries would enable working mothers to continue to work after delivery. The establishment of care houses for the elderly (a task usually delegated to women), the provision of free healthcare for everyone, and the development of the official public schooling at all its stages are additional measures that would ensure women's continued contribution to the formal economy.

Alexandra Kollontai, a renowned Russian communist, says: "for it is not her specific feminine virtue that gives her a place of honor in human society, but the worth of the useful mission accomplished by her, the worth of 


\section{Kohl 5.2}

88 her personality as human being, as citizen, as thinker, as fighter."2 To conclude, the pivotal stages in the life of any system, translated into the crises it goes through, are meant to be openings for change to the existing structures so to correct the order of inequality, inequity, and injustice. In this instance, such work is necessary for women not to remain on the societal and economic margins.

2 Alexandra Kollontai, "The Autobiography of a Sexually Emancipated Communist Woman," 1971, available on https://www.marxists.org/archive/kollonta/1926/autobiography.htm\#4b 